\title{
THE POSITION OF THE OXYGEN DISSOCIATION CURVE OF THE BLOOD IN NORMAL CHILDREN AND ADULTS ${ }^{1}$
}

\author{
By MINERVA MORSE, DONALD E. CASSELS, AND MELBA HOLDER, with THE \\ TECHNICAL ASSISTANCE OF EDNA O'CONNELL AND AXEL SWANSON
}

(From the Department of Pediatrics, University of Chicago Clinics, Chicago)

(Submitted for publication April 14, 1950; accepted, May 22, 1950)

Oxyhemoglobin dissociation curves were determined in normal children and adults as a preliminary to a study of such curves in patients with cyanotic congenital heart disease. A comparison of the curves of normal children with those of normal adults showed that the dissociation curves of children tend to lie to the right of those of the adult. In order to confirm this observation, the study was extended to include more cases and a wide range of ages. This report presents the results of the study.

The report consists of a comparison between the positions of the oxyhemoglobin dissociation curves of the child and the adult in a group of 21 children two to ten years of age and 22 adults 21 to 45 years of age. In addition, it includes oxygen dissociation data for six newborn infants less than one day old, for a group of 15 older infants varying in age from 11 days to two years, and for a group of nine pre-adolescents, adolescents and post-adolescents from 11 to 20 years of age. The older infants were included in order to determine whether the slight shift of the curve to the right in childhood is greater in infancy. The older children were studied in the hope of determining the approximate age at which the leftward shift to the normal adult position occurs.

\section{SUBJECTS AND METHODS}

Subjects: The newborn infants were born at term by normal delivery. The older infants and children were carefully selected normals, free from circulatory, pulmonary or metabolic disturbances. The adults of the study were members of the laboratory, resident or medical staff.

Methods: The methods employed were essentially those described by D. B. Dill in the high altitude report of Keys, Hall and Barron (1). Samples of blood $(4 \mathrm{ml}$.) were equilibrated for 20 minutes at $37^{\circ} \mathrm{C}$. in tonometers of approximately $325 \mathrm{ml}$. capacity which contained nitrogen, carbon dioxide at approximately $40 \mathrm{~mm}$. tension, and oxygen in amounts designed to give one fully oxygenated

1 This work was conducted under a grant from the Douglas Smith Foundation at the University of Chicago. sample $\left(\mathrm{pO}_{2}\right.$ approximately $\left.185 \mathrm{~mm} . \mathrm{Hg}\right)$ and five points on the dissociation curve, usually between 20 and 90 per cent saturation. The samples when drawn were mixed with heparin and kept in ice water. After equilibration they were stored in sampling tubes over mercury and were kept in ice water until the analyses for carbon dioxide and oxygen by the Van Slyke-Neill manometric method (2) were completed. Analyses were completed within eight hours after drawing the sample. The oxygen and carbon dioxide concentrations of the gas phase of the tonometers were determined by Haldane analysis.

The $\mathrm{pH}_{\mathrm{c}}$ of each equilibrated sample was calculated from the Henderson-Hasselbalch equation with values of $\mathrm{pK}_{\mathrm{c}}$ taken from the nomogram of Keys, Hall and Barron (1). The experimentally determined relation of the oxygen pressure in the gas phase of the tonometer to the percentage oxygen saturation of the hemoglobin in the blood cells was in each case corrected to a constant $\mathrm{pH}_{\mathrm{c}}$ of 7.1 by use of the factor, $\frac{\Delta \log \mathrm{pO}_{2}}{\Delta \mathrm{pH}_{\mathrm{c}}}=-0.568$, as given by Keys, Hall and Barron (1).

The oxygen pressures corresponding to saturations of $30,40,50,60,70$, and 80 per cent were determined for each individual by interpolation from a graph in which the logarithms of the oxygen pressures, corrected to a $\mathrm{pH}_{\mathrm{c}}$ of 7.10 , were plotted against the corresponding percentage saturations. The approximately linear relation between percentage saturation and the logarithm of the oxygen pressure at this range of saturation facilitates interpolation.

\section{RESULTS}

Table I gives for both children and adults the means and their standard errors, the standard deviations of distribution, and the " $t$ " values which were calculated to test the significance of observed differences between the means of the $\mathrm{pO}_{2}$ values of children and those of adults at given percentage saturations. Figure 1 shows the range of distribution of the $\mathrm{pO}_{2}$ values corresponding to percentage saturations of $30,40,50,60,70$ and 80 for both children and adults. At 30 per cent saturation the mean $\mathrm{PO}_{2}$ and the distribution of individual values for children and adults are similar, but above this level the dissociation curves which connect the means at increasing saturations sepa- 
TABLE I

Mean oxygen pressures corresponding to 30,40,50,60,70, and 80 per cent oxygen saturation of the hemoglobin in the blood of normal children and adults

\begin{tabular}{|c|c|c|c|c|c|c|c|c|c|c|}
\hline \multirow{2}{*}{$\begin{array}{l}\text { Percentage } \\
\text { saturation }\end{array}$} & \multicolumn{4}{|c|}{ Children } & \multicolumn{4}{|c|}{ Adults } & \multirow{2}{*}{$\begin{array}{c}\text { Difference } \\
\text { between the } \\
\text { mean } \mathrm{pO}_{2}\end{array}$} & \multirow{2}{*}{$\begin{array}{l}\text { Test of } \\
\text { significance } \\
\text { " } t \text { " }\end{array}$} \\
\hline & $\begin{array}{l}\text { No. } \\
\text { cases }\end{array}$ & $\underset{\substack{\text { Mean } \\
\mathrm{pO}_{2}}}{2}$ & S.D. & $\begin{array}{l}\text { S.E. of } \\
\text { the mean }\end{array}$ & $\begin{array}{l}\text { No. } \\
\text { cases }\end{array}$ & $\begin{array}{c}\text { Mean } \\
\mathrm{pO}_{2}\end{array}$ & S.D. & $\begin{array}{l}\text { S.E. of } \\
\text { the mean }\end{array}$ & & \\
\hline $\begin{array}{l}80 \\
70 \\
60 \\
50 \\
40 \\
30\end{array}$ & $\begin{array}{l}20 \\
22 \\
22 \\
22 \\
19 \\
17\end{array}$ & $\begin{array}{c}m m . H g \\
44.08 \\
35.67 \\
29.97 \\
25.27 \\
21.30 \\
17.73\end{array}$ & $\begin{array}{c}m \boldsymbol{m} . \mathrm{Hg} \\
2.09 \\
1.16 \\
0.99 \\
0.94 \\
0.79 \\
0.85\end{array}$ & $\begin{array}{c}m m . H g \\
0.47 \\
0.25 \\
0.22 \\
0.21 \\
0.18 \\
0.21\end{array}$ & $\begin{array}{l}22 \\
22 \\
22 \\
22 \\
19 \\
11\end{array}$ & $\begin{array}{c}m m . H g \\
41.34 \\
33.83 \\
28.44 \\
24.09 \\
20.52 \\
17.70\end{array}$ & $\begin{array}{c}m m . H g \\
1.75 \\
1.59 \\
1.31 \\
1.34 \\
1.32 \\
1.05\end{array}$ & $\begin{array}{c}m m . ~ H g \\
0.37 \\
0.34 \\
0.28 \\
0.29 \\
0.30 \\
0.32\end{array}$ & $\begin{array}{c}m m . \mathrm{Hg} \\
2.74 \\
1.74 \\
1.53 \\
1.18 \\
0.78 \\
0.03\end{array}$ & $\begin{array}{l}4.61 \\
4.34 \\
4.30 \\
3.33 \\
2.21 \\
0.08\end{array}$ \\
\hline
\end{tabular}

rate. The curve for the blood of children lies slightly to the right of the curve for adults.

The differences between the mean $\mathrm{pO}_{2}$ values for children and those for adults increase from $0.8 \mathrm{~mm}$. at 40 per cent saturation to $2.7 \mathrm{~mm}$. at 80 per cent saturation. These differences, while small, appear to be statistically significant according to Fisher's " $t$ " test, with the possible exception of the difference at 40 per cent saturation. Although at a given percentage saturation the $\mathrm{pO}_{2}$ values of many of the children and adults are identical, Figure 1 shows that with increasing percentage saturation the $\mathrm{pO}_{2}$ values for most of the adults studied are lower than those of all but the exceptional child. At 80 per cent saturation only two of the children showed $\mathrm{pO}_{2}$ values as low as those of 68 per cent of the adults.

Figure 2 shows the distribution of $\mathrm{pO}_{2}$ values at 50 per cent saturation for the blood of a group of newborn and older infants. In agreement with previous studies reported in the literature $(3,4)$ the dissociation curve of the newborn infant was found to lie to the left of that of the normal adult. Individual variations were much smaller than in

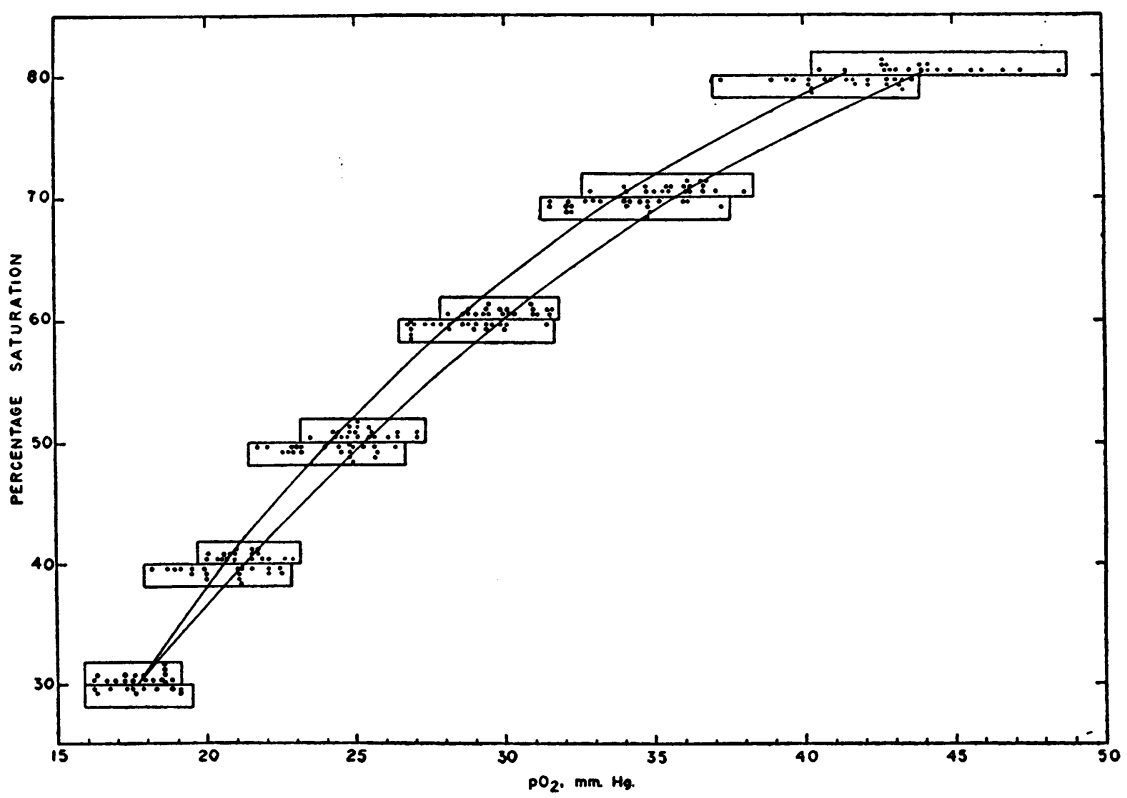

Fig. 1. Mean Oxygen Dissociation Curves of the Blood of Normal Children and Adults for Saturations Between 30 and 80 Per Cent

The plotted points represent the range of individual variation of the $\mathrm{pO}_{2}$ values at oxygen saturations of $30,40,50,60,70$, and 80 per cent. The upper block at each percentage saturation contains $\mathrm{pO}_{2}$ values for children, the lower block those for adults. 


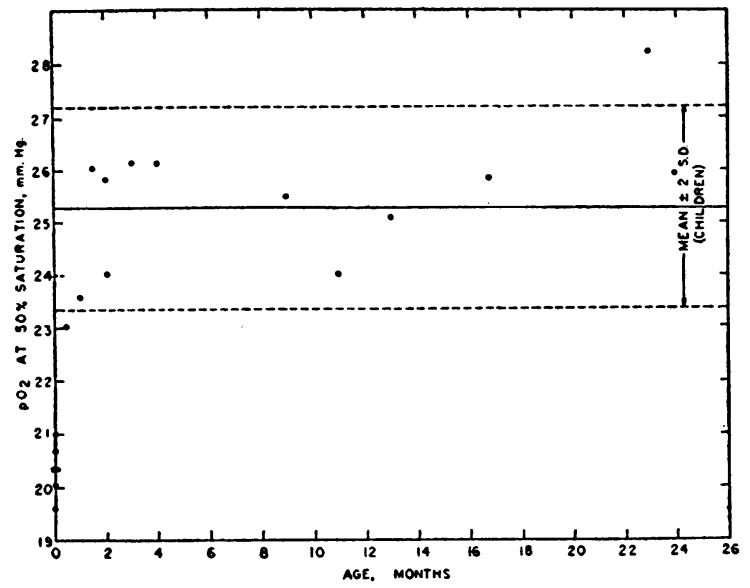

Fig. 2. Distribution of $\mathrm{PO}_{2}$ Values at 50 Per Cent Saturation for a Group of Six Newborn and 13 OLder Infants

For comparison, the mean and the range of variation represented by two standard deviations from the mean, for children two to ten years of age, are shown by the solid and broken lines, respectively.

any other group investigated. The one infant studied within the first month of life confirms the observation of Darling and his associates (4) that the shift to the adult position of the dissociation curve begins soon after birth. The blood of all but one of the infants one month of age or older gave $\mathrm{pO}_{2}$ values at 50 per cent saturation which were within the range of variation found for children. The evidence at hand is insufficient, but the few cases studied suggest that the position of the dissociation curve of the blood of infants over two months of age does not differ from that of the child.

The plotted points in Figure 3 represent $\mathrm{pO}_{2}$ values at 50 per cent saturation for the blood of individuals between ten and 21 years of age. With one exception, that of an 18 year old male, all values lie either close to or higher than the mean for children two to ten years of age, but within the range of variation of that group. The results suggest that the dissociation curve of the blood may tend to lie slightly farther to the right during adolescence than it does during childhood. In the very limited data available there is no evidence that the shift leftward toward the adult position has begun before the age of 21 years. Because of the relatively large range of individual variation and the small difference between the mean position of the dissociation curve of adolescents and that of adults, an estimate of the time of transition from the adolescent to the adult position would require statistical treatment of data from many individuals between 16 and 24 years of age.

\section{DISCUSSION}

The methods of the Harvard Fatigue Laboratory have been used by a number of investigators to determine the position of the oxygen dissociation curve in the blood of normal adults. The mean position of that curve, as established by the present data, lies slightly to the left of those curves described in the reports of Keys, Hall and Barron (1) and Keys and Snell (5) for normal adult males and of Darling and his coworkers (4) for normal adult females. The mean dissociation curves of these three reports agree very closely. On the other hand, a similar curve, describing results secured by the same methods by Aste-Salazar and Hurtado (6) for residents at sea level in Peru, agrees essentially with the adult curve of our study although we found the range of individual variation to be greater.

Aste-Salazar and Hurtado were at a loss to know whether the difference in the position of their mean curve was due to technical variations in the methods employed or to racial or environmental variations. In the present instance effects of environmental and racial factors would seem to

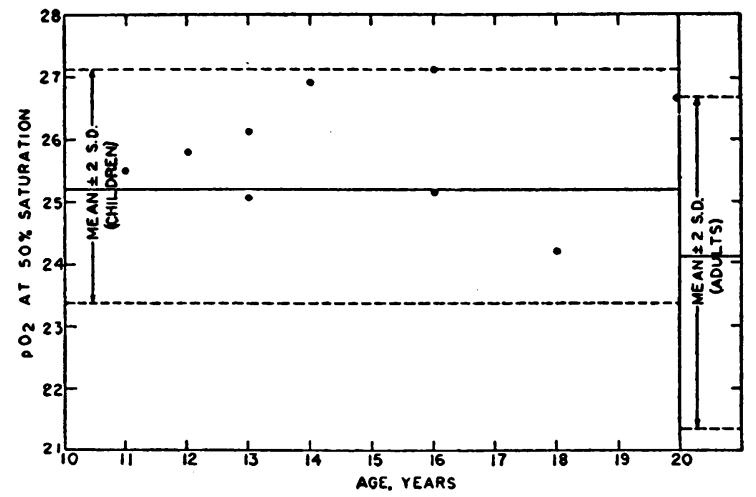

Fig. 3. Distribution of $\mathrm{PO}_{2}$ Values at 50 Per Cent Saturation for a Group of Individuals Between 11 AND 20 YeARS OF AGE

For comparison, the means and the ranges of variation represented by two standard deviations from the mean are shown by the solid and broken lines, respectively, for children and adults as indicated. 
be ruled out. The differences are probably not the result of sampling, for comparison at 50 per cent saturation, at which point individual data are given in all reports, shows that the blood of only one of our 22 adult subjects, who were chosen at random, showed a $\mathrm{pO}_{2}$ value as high as $26 \mathrm{~mm}$. $\mathrm{Hg}$, the average in all previous studies except that of Aste-Salazar and Hurtado. This suggests that variation in results from different laboratories is probably to be attributed to unknown technical differences. It is of interest to note that the points plotted by Drabkin (7), in which per cent $\mathrm{HbO}_{2}$ was based on direct spectrophotometric analysis and corresponding $\mathrm{pO}_{2}$ determinations were made directly on arterial blood "equilibrated" in vivo, agree more closely with the position of the dissociation curve determined from gasometric data in our laboratory than from data reported earlier.

The data reported here indicate a tendency toward increased affinity of hemoglobin for oxygen in the blood of the adult as compared with that of the child. The shift farther to the left in fetal blood may be attributed to the presence of a fetal type of hemoglobin which possesses greater affinity for oxygen than does the adult type. The existence of a fetal type of human hemoglobin which is different from the adult is now substantiated by a number of different methods: crystal structure of the $\mathrm{HbO}_{2}, \mathrm{HbCO}$, and $\mathrm{MetHb}$ compounds, solubility behavior of these compounds, resistance to alkali denaturation, rate of spreading of monomolecular layers on the surface of a liquid, electrophoretic mobility, immunological behavior, amino acid composition, and the position of the tryptophane absorption band in the ultraviolet region of the spectrum. A number of reports contain extensive references to the literature on the subject (8-16). The molecular weight of the fetal type is the same as the adult type of hemoglobin $(15,17)$. The difference appears to lie in the globin part of the molecule (18).

There have been reports in the literature, based chiefly on studies of resistance to alkali denaturation and of the rate of spreading of monomolecular layers on the surface of a liquid, to the effect that there are two different adult forms of hemoglobin $(8,19-25)$. If such were the case, and if the two forms possessed different affinities for oxygen, the wide range of individual variation and the tend- ency toward increased affinity for oxygen in the blood of the adult could be explained by the varying proportions of the two forms. This question is still open. Jope and O'Brien (14) found no evidence of more than one component from solubility studies of human adult $\mathrm{HbO}_{2}, \mathrm{HbCO}$, and MetHb. They also report that electrophoresis and ultracentrifuge studies on the same crystalline adult $\mathrm{HbCO}$ and $\mathrm{HbO}_{2}$ show the protein to be homogeneous.

Other factors which are known to cause a shift in the position of the dissociation curve are temperature, $\mathrm{pH}, \mathrm{CO}_{2}$ per se, and electrolyte environment. The first three were controlled by the conditions of the experiment. Temperature was maintained at $37^{\circ} \mathrm{C}$. during the equilibration, average carbon dioxide tensions in the tonometers were $37.6 \mathrm{~mm}$. and $38.1 \mathrm{~mm}$. $\mathrm{Hg}$ for children and adults, respectively, and the average $\mathrm{pH}_{c}$ of the equilibrated blood samples from children was 7.09 as compared with 7.11 for those from adults. The effect of small variations in the $\mathrm{pH}_{\mathrm{c}}$ from 7.10 was eliminated by use of the correction factor of Keys, Hall and Barron (1). In contrast, the electrolyte environment within the red cell offers a variable which cannot be controlled and about which comparatively little is known. The question of the nature of possible differences in electrolyte concentrations within the red corpuscle of the child as compared with that of the adult, and the effect of such differences on the dissociation curve of oxyhemoglobin must be considered.

The effect of electrolytes upon the dissociation curve has been recognized since the reports of Barcroft and Camis (26) and Barcroft and Roberts (27) in 1909. Sidwell and his colleagues (28) studied the effect of single electrolytes upon the oxygenation of purified human hemoglobin in solution at a $\mathrm{pH}$ of 6.8 and found that the inhibiting effect upon oxygenation varied with the individual electrolyte. Bicarbonate- $\mathrm{CO}_{2}$ and phosphate buffers were much more inhibiting than citrate, sulfate and chloride salts. They concluded that the inhibiting effect of electrolytes upon the oxygenation of purified hemoglobin was not due entirely to ionic strength but also to the coordinate attachment of anions about the iron atom of the hemoglobin molecule. They pointed out that at a $\mathrm{pH}$ of 6.8 carbamate formation of $\mathrm{CO}_{2}$ with hemoglobin does not occur. Hermann and col- 
leagues (29) have since shown that in the physiological range above 7.0 much of the bicarbonate effect can be attributed to the partial conversion of hemoglobin to a carbamino compound by reaction with free $\mathrm{CO}_{2}$. They found also that in the presence of bicarbonate and $\mathrm{CO}_{2}$ the effect of phosphate upon the oxyhemoglobin dissociation equilibrium almost disappeared. Studying the effect of cations, Hill and Wolvekamp (30) found that in dilute solutions of hemoglobin in phosphate buffers the potassium buffer shifted the dissociation farther to the right than did the sodium buffer. The results of Sidwell and colleagues (28) and of Hermann and associates (29) indicate that the influence of the potassium ion is not great.

Table II summarizes values found in the literature $(31-40)$ for the sodium, potassium and chloride concentrations within the red corpuscle. It is evident that a true comparison of the electrolyte concentrations in the red cell of the child and the adult must depend upon values determined in the same laboratory and by the same methods. The results of Erickson and colleagues (40) for the child suggest that the potassium ion concentration may be somewhat higher in the child's corpuscles, but that the sodium and chloride concentrations are probably similar. Since the potassium ion greatly predominates over the other cations in the red cell, it is conceivable that the higher concentration in the child may explain in part the decreased affinity of hemoglobin for oxygen in the blood of the child.
To our knowledge the literature contains no information concerning the bicarbonate concentration in the red cell of the child. Both Robinson's (41) study and results in our laboratory have shown that at a $\mathrm{CO}_{2}$ tension of $40 \mathrm{~mm}$. $\mathrm{Hg}$, the bicarbonate concentration in the plasma tends to be lower in children of six years or younger than in older children, and that the level in older children is in turn one milliequivalent per liter lower than in adults. The average age of the children whose dissociation curves were studied was slightly under six years. If the distribution of bicarbonate ions between cells and plasma is the same in the child as in the adult, it can be assumed that for a given $\mathrm{CO}_{2}$ tension the bicarbonate concentration would tend to be lower in the red cell of the child. According to the results of Sidwell and his coworkers (28) a higher bicarbonate concentration would be expected to decrease the affinity of hemoglobin for oxygen. Since the reverse was found, it must be assumed that any effect of the bicarbonate ion is counterbalanced by some other factor.

A consideration of the acid-balance within the red cell of the child suggests that the unknown anion residue, $\mathrm{X}^{-}$, is higher than in that of the adult, for the fixed base concentration appears to be higher because of the higher potassium concentration, while the sum of known anions tends to be lower because of lower bicarbonate and hemoglobinate with equal chloride concentrations. To what extent the affinity of hemoglobin for oxygen is influenced by the presence of such undetermined anions is unknown.

TABLE II

A summary of values found in the literature for the sodium, potassium, and chloride concentrations in the red blood corpuscle

\begin{tabular}{|c|c|c|c|c|c|c|c|c|c|}
\hline & \multirow{2}{*}{\multicolumn{2}{|c|}{ Investigator }} & \multirow{2}{*}{ Method } & \multicolumn{2}{|c|}{ Sodium } & \multicolumn{2}{|c|}{ Potassium } & \multicolumn{2}{|c|}{ Chloride } \\
\hline & & & & Average & Range & Average & Range & Average & Range \\
\hline$\frac{3}{3}$ & $\begin{array}{l}\text { Kramer and Tisdall } \\
\text { Dill, Talbott and } \\
\text { Edwards } \\
\text { Butler and McKay } \\
\text { Oberst } \\
\text { Maizels } \\
\text { Crabtree } \\
\text { Hald and Eisenman } \\
\text { Thelen } \\
\text { Snyder and Katzenel- } \\
\text { bogen }\end{array}$ & $\begin{array}{l}(31) \\
(32) \\
(33) \\
(34) \\
(35) \\
(36) \\
(37) \\
(38) \\
(39)\end{array}$ & $\begin{array}{l}\text { Indirect } \\
\text { Direct } \\
\text { Direct } \\
\text { Direct } \\
\text { Direct } \\
\text { Total base- }(\mathrm{K}+\mathbf{M g}) \\
\text { Indirect } \\
\text { Indirect } \\
\text { Direct-Methods of } \\
\text { Hald and Eisenman }\end{array}$ & $\begin{array}{c}\text { meq./l. } \\
-2 \\
15 \\
18 \\
13 \\
12 \\
11 \\
17 \\
42 \\
13\end{array}$ & $\begin{array}{l}\text { meq./l. } \\
-7-+2 \\
13-17 \\
15-23 \\
10-15 \\
10-15 \\
10-23 \\
10-27 \\
16-57 \\
4-16\end{array}$ & $\begin{array}{c}\text { meq./l. } \\
109 \\
93 \\
88 \\
106 \\
83 \\
97 \\
86\end{array}$ & $\begin{array}{c}\text { meq./l. } \\
105-113 \\
89-99 \\
83-91 \\
101-110 \\
72-102 \\
91-104 \\
81-94\end{array}$ & $\begin{array}{c}\text { meq./l. } \\
53 \\
54 \\
51\end{array}$ & $\begin{array}{l}m e q . / l . \\
51-56 \\
52-55 \\
48-56 \\
\\
43-59 \\
54-64\end{array}$ \\
\hline 实导 & $\begin{array}{l}\text { Erickson, Williams, } \\
\text { Hummel and Macy }\end{array}$ & (40) & Indirect & 16 & 4-27 & 115 & $100-142$ & 53 & $35-82$ \\
\hline
\end{tabular}


In a study of anemias Litarczek, and his associates (42) found a relationship between the increased concentration of glutathione and the lowering of the oxygen dissociation curve. On the other hand Hill and Wolvekamp (30) reported that pure glutathione, in concentrations of 0.03 and 0.3 per cent, produced no shift in the curve of dilute human hemoglobin at a $\mathrm{pH}$ of 7.4 , although the form of the curve became more Sshaped. Observations of McNamara and Senn (43) indicate that the red cells of children from two to 11 years of age contain less glutathione than is found in the red cells of adults. Any effect of differences in the glutathione concentration within the red cells would therefore appear to be in a direction opposite to the decreased affinity of hemoglobin for oxygen which has been observed in the blood of the child.

The work of Polonowski, Santenoise and Stankoff (44) suggests that certain hormones exert an effect on the affinity of hemoglobin for oxygen. If such be the case, the presence of a growth hormone may explain the decreased affinity of hemoglobin for oxygen in the blood of the child.

The slopes of the dissociation curves for the child and adult appear to differ slightly since they separate more widely as the percentage saturation increases but coincide at 30 per cent saturation. When the data are plotted as $\log \frac{\mathrm{Hb}}{\mathrm{HbO}_{2}}$ against $\log \mathrm{pO}_{2}$, the slope of the best fitting straight line through the plotted points gives the value of " $n$ " in Hill's equation for the sigmoid curve, $\mathrm{Y}=$ $\frac{\mathrm{Kp}^{\mathrm{n}}}{1+\mathrm{Kp}^{\mathrm{n}}}$. Although this equation has lost its physical meaning since Adair's discovery $(45,46)$ that the molecule of hemoglobin contains four heme groups, it fits the data quite well for the range of saturation included in this study and gives a convenient estimate of the slope of the curve. The mean " $n$ " values were found to be $2.55 \pm$ 0.05 for the child and $2.62 \pm 0.03$ for the adult, with a " $t$ " value of 1.24 , a difference too small to be considered significant.

The adults of our study covered the age range of 21 to 45 years. There was no evidence of variation with age during those years. Dill and his associates (47) compared the position of the dissociation curve in a group of 12 men 57 to 81 years of age with that of a younger group of adults and found no difference attributable to age during adult life.

\section{SUM MARY}

The oxygen dissociation curve of the blood of the child, determined by the in vitro tonometer method, tends to lie farther to the right than does that of the adult, i.e., in the direction of decreased affinity of hemoglobin for oxygen.

The shift in position from that of the newborn infant, which lies to the left of the normal adult curve, to that of the child occurs within the first two months of life.

\section{BIBLIOGRAPHY}

1. Keys, A., Hall, F. G., and Barron, E. S. G., The position of the oxygen dissociation curve of human blood at high altitude. Am. J. Physiol., 1936, 115, 292.

2. Peters, J. P., and Van Slyke, D. D., Quantitative Clinical Chemistry; Vol. II, Methods. Williams \& Wilkins Co., Baltimore, 1932.

3. Leibson, R. G., Likhnitzky, I. I., and Sax, M. G., Oxygen transport of the fetal and maternal blood during pregnancy. J. Physiol., 1936, 87, 97.

4. Darling, R. C., Smith, C. A., Asmussen, E., and Cohen, F. M., Some properties of human fetal and maternal blood. J. Clin. Invest., 1941, 20, 739.

5. Keys, A., and Snell, A. M., Respiratory properties of the arterial blood in normal man and in patients with disease of the liver: position of the oxygen dissociation curve. J. Clin. Invest., 1938, 17, 59.

6. Aste-Salazar, H., and Hurtado, A., The affinity of hemoglobin for oxygen at sea level and at high altitudes. Am. J. Physiol., 1944, 142, 733.

7. Drabkin, D. L., Aspects of the oxygenation and oxidative functions, in: Haemoglobin, edited by Roughton, F. J. W., and Kendrew, J. C. Interscience Publishers, Inc., New York, 1949, p. 35.

8. Brinkman, R., and Jonxis, J. H. P., The occurrence of several kinds of haemoglobin in human blood. J. Physiol., 1935, 85, 117.

9. Wyman, J., Jr., Rafferty, J. A., and Ingalls, E. N., Solubility of adult and fetal carbonylhemoglobin of the cow. J. Biol. Chem., 1944, 153, 275.

10. Andersch, M. A., Wilson, D. A., and Menten, M. L., Sedimentation constants and electrophoretic mobilities of adult and fetal carbonylhemoglobin. J. Biol. Chem., 1944, 153, 301.

11. Barcroft, J., Researches on Pre-Natal Life. Charles C. Thomas, Springfield, IIl., 1948.

12. Jope, E. M., The ultra-violet spectral absorption of haemoglobins inside and outside the red blood cell, in: Haemoglobin, edited by Roughton, F. J. W., and Kendrew, J. C. Interscience Publishers, Inc., New York, 1949, p. 205. 
13. Jonxis, J. H. P., Foetal haemoglobin and Rh antagonisms. Ibid, p. 261.

14. Jope, H. M., and O'Brien, J. R. P., Crystallization and solubility studies. Ibid, p. 269.

15. Gutfreund, H., The osmotic pressure of haemoglobin in strong salt solutions. Ibid, p. 197.

16. Kendrew, J. C., Foetal haemoglobin. Endeavour, 1949, 8, 80.

17. Taylor, J. F., and Swarm, R. L., Molecular weight of human fetal hemoglobin. Federation Proc., 1949, 8, 259.

18. Haurowitz, F., Zur Chemie des Blutfarbstoffes. XI. Uber das Hämoglobin des Menschen. Ztschr. f. physiol. Chem., 1930, 186, 141.

19. Derrien, Y., and Roche, J., Sur L'hémoglobine foetale humaine. Compt. Rend. Soc. de Biol., 1948, 142, 1001.

20. Schenk, E. G., Untersuchungen über das Globin bei Tieren, gesunden und kranken Menschen. Ein Beitrag zur Kenntnis der dynamischen Konstitution des Hämoglobins. Arch. f. exper. Path. u. Pharmakol., 1930, 150, 160.

21. Geiger, A., Isolation by cataphoresis of two different oxyhemoglobins from the blood of some animals. Proc. Roy. Soc. London, 1931, 107B, 368.

22. Lang, K., Uber die Zusammensetzung des Globins bei gesunden und anämischen Menschen. Arch. f. exper. Path. u. Pharmakol., 1933, 174, 63.

23. Brinkman, R., Wildschut, A., and Wittermans, A., On the occurrence of two kinds of haemoglobin in normal human blood. J. Physiol., 1934, 80, 377.

24. Altschul, A. M., Sidwell, A. E., Jr., and Hogness, T. R., Note on the preparation and properties of hemoglobin. J. Biol. Chem., 1939, 127, 123.

25. Roche, J., Derrien, Y., and Moutte, M., Sur 1a spécificité des hémoglobines et sur l'existence probable de deux hémoglobines dans le sang de divers mammifères. Compt. Rend. Soc. de Biol., 1941, 135, 1235.

26. Barcroft, J., and Camis, M., The dissociation curve of the blood. J. Physiol., 1909, 39, 118.

27. Barcroft, J., and Roberts, F., The dissociation curve of haemoglobin. J. Physiol., 1909, 39, 143.

28. Sidwell, A. E., Jr., Munch, R. H., Barron, E. S. G., and Hogness, T. R., The salt effect of the hemoglobin-oxygen equilibrium. J. Biol. Chem., 1938, 123, 335.

29. Hermann, H., Hudoffsky, B., Netter, H., and Travia, L., Uber den spezifischen Einfluss der Kohlensäure auf die Sauerstoffbindungskurve des Hämoglobins. Arch. f. d. ges. Physiol., 1939, 242, 311.

30. Hill, R., and Wolvekamp, H. P., The oxygen dissociation curve of haemoglobin in dilute solution. Proc. Roy. Soc. London, 1936, 120B, 484.

31. Kramer, B., and Tisdall, F. F., Distribution of so- dium, potassium, calcium and magnesium between corpuscles and serum of human blood. J. Biol. Chem., 1922, 53, 241.

32. Dill, D. B., Talbott, J. H., and Edwards, H. T., Studies in muscular activity. VI. Response of several individuals to a fixed task. J. Physiol., 1930, 69, 267.

33. Butler, A. M., and McKay, E. M., The influence of the sodium and potassium content of the diet upon the sodium concentration of human centrifuged red blood cells. J. Biol. Chem., 1934, 106, 107.

34. Oberst, F. W., The determination of sodium in human red cells. J. Biol. Chem., 1935, 108, 153.

35. Maizels, M., The anion and cation contents of normal and anaemic bloods. Biochem. J., 1936, 30, 821.

36. Crabtree, M. G., and Maizels, M., The sodium content of human erythrocytes. Biochem. J., 1937, 31, 2153.

37. Hald, P. M., and Eisenman, A. J., The distribution of bases between cells and serum of normal human blood. J. Biol. Chem., 1937, 118, 275.

38. Thelen, H., Der Gehalt von Plasma, Serum und Erythrocyten an Calcium, Kalium und Natrium. Ztschr. f. physiol. Chem., 1937, 250, 221.

39. Snyder, R., and Katzenelbogen, S., The distribution of sodium, potassium, calcium, magnesium, inorganic phosphorus and chloride between blood serum and cells of normal individuals. J. Biol. Chem., 1942, 143, 223.

40. Erickson, B. N., Williams, H. H., Hummel, F. C., and Macy, I. G., The lipid and mineral distribution in the serum and erythrocytes of normal children. J. Biol. Chem., 1937, 118, 15.

41. Robinson, S., Experimental studies of physical fitness in relation to age. Arbeitsphysiol., 1938, 10, 251.

42. Litarczek, G., Aubert, H., Cosmulesco, I., and Comanesco, V., L'influence du glutathione sur la courbe de dissociation de l'oxyhémoglobine. Compt. Rend. Soc. de Biol., 1932, 109, 779.

43. McNamara, H., and Senn, M. J. E., Glutathione and red cells in the blood in infancy and childhood. Am. J. Dis. Child., 1940, 59, 97.

44. Polonovski, M., Santenoise, D., and Stankoff, E., Sur un mécanisme hormonal de régulation de l'affinité de l'hémoglobine du sang pour l'oxygène. Compt. Rend. Soc. de Biol., 1943, 137, 92.

45. Adair, G. S., Direct method of measuring the osmotic pressure of haemoglobin. Proc. Roy. Soc. London, 1925, 108A, 627.

46. Adair, G. S., The osmotic pressure of haemoglobin in the absence of salts. Proc. Roy. Soc. London, 1925, 109A, 292.

47. Dill, D. B., Graybiel, A., Hurtado, A., and Taquini, A. C., Der Gasaustausch in den Lungen im Alter. Ztschr. f. Altersforschung, 1940, 2, 20. 